\title{
PENGARUH PROMOSI BERBASIS SOSIAL MEDIA TERHADAP PENJUALAN PRODUKSI KELOMPOK WANITA TANI (KWT) AYU TANGKAS DI DESA MEGATI
}

\author{
I M Dedy Setiawan ${ }^{1}$, N P Sukanteri ${ }^{2}$, I M Suryana ${ }^{3}$, P K Suparyana ${ }^{4}$ \\ ${ }^{1}$ Program Studi Teknik Informatika, STIKI Indonesia, Denpasar, Bali \\ ${ }^{2}$ Program Studi Agribisnis, Universitas Mahasaraswati Denpasar, Bali \\ ${ }^{3}$ Program Studi Agroteknologi, Universitas Mahasaraswati Denpasar, Bali \\ ${ }^{4}$ Program Studi Agribisnis, Universitas Mataram \\ e-mail: dedy.setiawan86@yahoo.com, putusukanteri@gmail.com \\ pandesuparyana@unram.ac.id, ekamtbn@yahoo.co.id
}

\begin{abstract}
Abstrak
Penelitian ini bertujuan untuk mengetahui bagaimana pengaruh promosi berbasis sosial media terhadap hasil penjualan produksi pertanian Kelompok Wanita Tani (KWT) Ayu Tangkas di Desa Megati Kabupaten Tabanan. Penelitian ini dilaksanakan di Desa Megati Kecamatan Selemadeg Barat Kabupaten Tabanan yang melibatkan KWT Ayu Tangkas yang berperan dalam mengolah hasil pertanian menjadi makanan yang siap jual. Penentuan responden ditunjuk secara purposive random sampling. Penelitian ini menggunakan pendekatan penelitian kualitatif, dan data yang diperoleh dianalisis secara deskriptif. Metode pengumpulan data dengan menggunakan teknik wawancara, observasi, dan dokumentasi. Hasil penelitian menunjukkan bahwa sarana promosi melalui sosial media mampu meningkatkan penjualan produksi KWT Ayu Tangkas sehingga layak digunakan sebagai media pemasaran produk hasil pertanian KWT Ayu Tangkas di Desa Megati..
\end{abstract}

Kata kunci : Kelompok Wanita Tani (KWT), Media Sosial, Produksi

\begin{abstract}
This study aims to determine how the influence of social media-based promotions on the sale of agricultural production in Farmer Women Group (KWT) Ayu Tangkas in Megati Village, Tabanan Regency. This research was conducted in Megati Village, Selemadeg Barat Subdistrict, Tabanan Regency, which involved the KWT Ayu Tangkas, which had a role in processing agricultural products into foods that were ready for sale. Determination of respondents was appointed by purposive random sampling. This study used a qualitative research approach, and the data obtained were analyzed descriptively. Methods of collecting data using interview, observation, and documentation techniques. The results showed that the means of promotion through social media were able to increase the sales of Ayu Tangkas KWT production so that it was suitable to be used as a medium for marketing agricultural products KWT Ayu Tangkas in Megati Village
\end{abstract}

Keywords : Women Farmers Group (KWT), Social Media, Production 


\section{PENDAHULUAN}

Desa Megati merupakan salah satu desa yang sebagian besar penduduknya menggantungkan sumber kehidupannya di sektor pertanian. Komoditi yang menonjol sebagai hasil andalan adalah padi, kelapa, kakao, dan kopi. Dari sektor pertanian ini, melahirkan beberapa sektor lain diantaranya adalah sektor industri rumah tangga yang mengolah hasil pertanian tersebut menjadi produk berupa makanan yang bernilai jual. Pengolahan hasil pertanian ini dilakukan oleh perempuan yang tergabung ke dalam Kelompok Wanita Tani (KWT) dalam bentuk kue-kue lokal dan pengolahan hasil pertanian dalam bentuk menu pendamping nasi. Kue yang diolah setiap hari merupakan kue yang dibutuhkan masyarakat setempat, selebihnya KWT ini menyediakan kue yang dibutuhkan untuk kebutuhan upacara.

Berdasarkan hasil observasi dan wawancara, diperoleh data bahwa masalah yang di hadapi KWT ini yaitu minimnya peralatan yang dimiliki untuk berproduksi, jenis kue yang di buat selalu monoton dan tidak ada variasi, pemasaran yang relatif rendah. Pemasaran hanya menunggu pemesaan saat upacara karena belum dikenal masyarakat luas. Mengingat pentingnya keberadaan KWT di desa Megati sebagai salah satu sumber pendapatan keluarga, disamping aspek fasilitas dan Sumber Daya Manusia (SDM), aspek pemasaran tentunya memegang peranan penting agar hasil produksi lebih dikenal masyarakat luas.

Seiring pesatnya perkembangan globalisasi, teknologi informasi menjadi pilihan pihak produsen untuk memasarkan produknya (Priambada 2015). Selain itu teknologi informasi juga mampu meningkatkan kesempatan para pelaku usaha untuk bekerjasama dengan pengusaha lainnya. Salah satu teknologi informasi yang sedang berkembang pesat dan sangat berpotensi untuk mendorong kinerja KWT dalam bidang pemasaran adalah melalui jejaring sosial. Hal ini didukung oleh pernyataan Indika \& Jovita (2017) yang menyatakan bahwa penggunaan jejaring sosial digunakan oleh masyarakat dalam melakukan banyak aktivitas mulai dari entertainment, melakukan bisnis, mencari info atau aktivitas lainnya. Hal ini menunjukkan bahwa peranan jejaring sosial dalam bentuk sosial media menjadi "senjata" yang ampuh dalam memasarkan sebuah produk.

Jejaring sosial hadir sebagai salah satu bagian dari perkembangan teknologi yang dapat menghubungkan secara instant antara satu individu dengan individu lain dengan menggunakan jaringan internet melalui berbagai media sosial yang tersedia dan dapat diakses oleh setiap orang yang telah memiliki akun dalam media sosial tersebut. Para pelaku usaha juga tidak mempermasalahkan lagi adanya keterbatasan jarak, ruang, dan waktu dengan hadirnya media sosial. Media sosial kini telah menjadi trend dalam komunikasi pemasaran (Purwidiantoro, S.W, \& Hadi 2016).

Media sosial seakan menjadi hal yang wajib dimiliki oleh setiap orang di era sekarang, dari anak-anak, remaja, sampai dewasa dengan berbagai macam kepentingan, mulai dari sekedar berselancar di dunia maya, bermain game, sampai pada pemanfaatan untuk bisnis. Media sosial bisa dikatakan menjadi kebutuhan di era industri 4.0 yang sedang "dikejar" di negeri ini, karena sebagian besar aktivitas seseorang memanfaatkan sarana internet untuk saling berinteraksi, mencari informasi, sampai dengan memasarkan hasil produksi.

Industri rumah tangga (home industry) seperti KWT merupakan salah satu kegiatan usaha secara kelompok yang terbentuk di tengah pesatnya perkembangan teknologi informasi. Tentu saja secara tidak langsung perkembangan teknologi ini akan berpengaruh terhadap perkembangan KWT kedepannya sehingga perlu adanya pembinaan yang sesuai agar KWT ini tetap ada sesuai dengan tujuan dan fungsinya.

Salah satu upaya pemasaran yang dapat digunakan oleh para pemilik home industry dalam memasarkan produk usaha mereka adalah dengan menggunakan media sosial sebagai sarana pemasaran bagi produk usaha tersebut. Media sosial seperti facebook, twitter, instagram dan media sosial lain yang telah memiliki banyak pengguna telah menjadi tempat dimana siapa saja bisa masuk dan mempublikasikan apa saja yang menjadi keinginan dari setiap pemilik akun tersebut. Salah satu media sosial yang kini sangat popular digunakan adalah instagram.

Instagram merupakan salah satu aplikasi berbagi foto maupun video, yang memungkinkan setiap pengguna untuk berinteraksi melalui fitur-fitur yang ada di dalamnya. Melalui instagram ini juga memungkinkan seseorang ataupun kelompok untuk mempromosikan berbagai produk untuk kepentingan bisnis secara visual. Kata "insta" berasal dari kata "instan", seperti kamera polaroid yang pada masanya lebih dikenal dengan sebutan "foto instan". Instagram juga dapat menampilkan foto-foto secara instan, seperti polaroid didalam tampilannya. 
Sedangkan untuk kata "gram" berasal dari kata "telegram", dimana cara kerja telegram sendiri adalah untuk mengirimkan informasi kepada orang lain dengan cepat. Oleh karena itulah Instagram berasal dari instan-telegram.

Karakteristik di dalam media sosial Instagram adalah dengan mengikuti akun pengguna lainnya, atau memiliki pengikut Instagram. Dengan demikian komunikasi antara sesama pengguna Instagram dapat terjalin dengan memberikan "double tap" atau "like" yang berarti tanda menyukai gambar yang diposting pada instagram dan juga mengomentari foto-foto yang telah diunggah oleh pengguna lainnya. Pengikut juga menjadi salah satu unsur yang penting, dimana jumlah tanda suka dari para pengikut sangat mempengaruhi apakah foto tersebut dapat menjadi sebuah foto yang populer atau tidak. Semakin banyak tanda suka yang dimiliki dalam sebuah foto, maka foto tersebut akan semakin populer.

Kegunaan utama dari Instagram adalah sebagai tempat untuk mengunggah dan berbagi foto-foto kepada pengguna lainnya. Para pelaku bisnis memanfaatkan fitur-fitur yang ada pada aplikasi instagram untuk mempromosikan serta memperluas jangkauan pemasaran berbagai produknya. Mulai dari unggah foto dan video, instagram story, followers, Geotagging, Hashtag, likes, komentar, serta quotes dalam setiap proses promosi yang dilakukan. Foto yang ditampilkan tentuna dengan kualitas yang baik dan dengan tampilan yang menarik. Selain itu aspek strategi pemasaran juga penting dirancang agar promosi yang dilakukan bisa dengan efektif dan efisien, sehingga mampu meningkatkan jumlah konsumen yang akan membeli ataupun menggunakan produk tersebut.

Ada beberapa penelitian relevan yang pernah dilakukan sebelumnya diantaranya yaitu pengaruh media sosial terhadap minat beli konsumen (studi kasus mahasiswa manajemen Universitas Pasir Pengaraian) oleh Setiawati et al. (2015). Hasil penelitian menunjukkan bahwa media sosial berpengaruh secara signifikan terhadap minat beli konsumen mahasiswa Program Studi Manajemen Universitas Pasir Pengaraian. Penelitian dengan judul Pemanfaatan Instagram Sebagai Sarana Promosi oleh Pengelola Industri Kreatif Fashion di Kota Bandung (Gumgum Gumelar 2015). Hasil penelitian menunjukkan bahwa penggunaan media sosial instagram cukup efektif digunakan sebagai sarana promosi industri fashion di Kota Bandung. Penelitian lain yaitu oleh (Echan et al. 2013) tentang Analisis Penggunaan Media Sosial untuk Mendukung Pemasaran Produk UMKM (Studi Kasus Kabupaten Subang, Jawa Barat). Hasil penelitian menunjukkan bahwa pemasaran produk oleh pelaku usaha masih dalam skala kecil dan belum memanfaatkan sosial media sehingga tidak berdampak signifikan terhadap penjualan produk. Untuk itu melalui penelitian ini akan dikaji lebih lanjut dengan memanfaatkan sosial media sebagai sarana promosi pemasaran produk UMKM.

Berdasarkan uraian latar belakang di atas, peneliti tertarik untuk mempromosikan produk pengolahan hasil pertanian KWT Ayu Tangkas di Desa Megati secara online melalui media sosial instagram.

\section{METODE}

Jenis penelitian yang dilakukan adalah penelitian deskriptif kualitatif. Penelitian dilaksanakan di Desa Megati, Kecamatan Selemadeg Barat, Kabupaten Tabanan. Populasi penelitian adalah Kelompok Wanita Tani (KWT) yang ada di Desa Megati.

Sampel penelitian diperoleh dengan menggunakan teknik purposive random sampling. Hal ini disebabkan karena peneliti dengan sengaja ingin langsung memperoleh data dari sampel yang dimaksud. Sampel dalam penelitian ini adalah KWT Ayu Tangkas yang beralamat di Br Megati Kelod.

Penelitian dilaksanakan selama 6 bulan yaitu mulai bulan Januari sampai bulan Juni 2019. Data dikumpulkan dengan menggunakan beberapa metode diantaranya wawancara, observasi, dan dokumentasi. Data yang diperoleh selanjutnya dianalisis secara deskriptif kualitatif.

\section{HASIL DAN PEMBAHASAN}

Desa Megati adalah desa yang menjadi pusat pemerintahan Kecamatan Selemadeg Timur Kabupaten Tabanan Provinsi Bali. Secara Demografi, Desa Megati merupakan daerah yang mempunyai kondisi fisik landai dan beberapa daerah berdataran tinggi. Pada dataran tinggi, ketinggian + $400 \mathrm{~s} / \mathrm{d} 500$ meter diatas permukaan laut, curah hujan relatif sedang dengan batas wilayah administratif sebagai berikut : Sebelah Utara berbatasan dengan Desa Gunung Salak, sebelah timur berbatasan dengan Desa Bantas dan Desa Mambang, sebelah selatan berbatasan dengan Desa Tangguntiti dan Desa Tegal Mengkeb, sebelah barat berbatasan dengan Desa Selemadeg dan Desa Serampingan. 
Luas wilayah Desa Megati, 8,423 km2 atau sekitar 2,00\% dari luas Kabupaten Tabanan. Secara administratif desa Megati terbagi atas 9 (sembilan) banjar dinas/dusun yang meliputi : banjar dinas Serampingan Kelod, banjar dinas Serampingan Kaja, banjar dinas Megati Kelod, banjar dinas Megati Kaja, banjar dinas Jelijih Tegeh, banjar dinas Jelijih Lebah, banjar dinas Jelijih Pondok, banjar dinas Sesandan Kauh, banjar dinas Sesandan Kangin. Jumlah penduduk Desa Megati berdasarkan hasil sensus pada tahun 2014, adalah sebanyak 2937 jiwa, terdiri dari 1446 jiwa penduduk laki-laki dan 1491 jiwa penduduk perempuan, yang terdiri dari 890 RT. Struktur penduduk menurut pendidikan menunjukkan kualitas sumber daya manusia yang dipunyai desa Megati, yaitu yang berusia pada usia pendidikan dasar 7 tahun s/d 16 tahun (pendidikan sekolah dasar dan menengah) yang belum pernah sekolah $0 \%$, sedang mengikuti pendidikan $100 . \%$ dan sisanya $0 \%$ tidak bersekolah lagi. Sedangkan yang berusia diatas 16 tahun (diatas usia pendidikan dasar) yang belum pernah sekolah $0 \%$, sedang mengikuti pendidikan $100 . \%$ dan sisanya $0 \%$ tidak bersekolah lagi, baik pada tingkat lanjutan dan perguruan tinggi.

Struktur penduduk menurut mata pencaharian menunjukkan bahwa sebagian besar penduduk menggantungkan sumber kehidupannya di sektor pertanian (60\%), sektor lain yang menonjol dalam penyerapan tenaga kerja adalah perdagangan (10.\%), sektor industri rumah tangga dan pengolahan (5.\%), sektor jasa (1\%) dan sektor lainnya seperti pegawai negeri, karyawan swata dari berbagai sektor (24\%).

Struktur perekonomian Desa Megati, masih bercorak agraris yang menitikberatkan pada sektor pertanian. Hal ini didukung oleh penggunaan lahan pertanian masih mempunyai porsi yang terbesar sebanyak $86,7 \%$ dari total penggunaan lahan desa. Juga $60,0 . \%$ mata

pencaharian

penduduk menggantungkan hidup pada sektor pertanian. Pada sektor ini komoditi yang menonjol sebagai hasil andalan adalah Padi, Kelapa, Kakao, Kopi,

Beberapa sektor ekonomi yang tergolong economic base dan menonjol di samping sektor pertanian adalah, perdagangan, industri rumah tangga dan pengolahan.

Pada sektor perdagangan meliputi pada pasar tradisional, warung, toko bangunan,jual beli hasil bumi. Sedangkan fasilitas pasar yang ada di desa Megati, yaitu 1 buah pasar Desa. Pada sektor industri rumah tangga dan pengolahan termasuk didalamnya adalah kerajinan ukir, jahit, Serkel, Pengolahan kue untuk upacara adat. Pada sektor jasa, yang menonjol adalah tumbuhnya lembaga/istitusi keuangan mikro berupa Koperasi, LPD sebagai pendukung ekonomi desa. Hal ini diharapkan akan membawa dampak positif dalam perkebangan ekonomi desa secara keseluruhan. Dsiamping itu sektor jasa yang lain adalah potong rambut/salon, foto kopi dan foto, bengkel motor/elektronik.

KWT Ayu Tangkas merupakan kelompok wanita tani yang bergabung dalam pengolahan hasil pertanian dalam bentuk kue -kue lokal dan pengolahan hasil pertanian dalam bentuk menu pendamping nasi. Kue yang diolah setiap hari merupakan kue yang dibutuhkan masyarakat setempat, selebihnya KWT ini menyediakan kue yang dibutuhkan untuk kebutuhan upacara. Ada tiga jenis kue yang diproduksi oleh KWT Ayu Tangkas yaitu kue Bendu, Pie, dan kue sus.

KWT Ayu Tangkas yang resmi dibentuk pada tanggal 26 September 2017 melalui surat pengukuhan Perbekel Desa Megati telah memiliki angota sebanyak 15 orang. Pada awal pembentukannya, proses produksi dan penjualan hasil produksi KWT Ayu Tangkas masih bersifat konvensional melalui informasi dari mulut ke mulut. Rata-rata anggota KWT ini sudah mampu menggunakan smartphone untuk melakukan komunikasi sehari-hari namun belum memanfaatkan media jejaring sosial untuk mempromosikan hasil produknya. Pemesanan juga masih bersifat lokal dan terbatas sehingga penjualan produk sifatnya masih insidental. Berdasarkan hasil wawancara dan studi dokumen, diperoleh informasi bahwa selama enam bulan terakhir sebelum tahun 2019, penjualan hasil produksi KWT Ayu Tangkas masih terbilang rendah dengan jenis kue yang tidak variatif serta kurang menarik. Secara statistik diperoleh rata-rata penjualan kue KWT Ayu Tangkas masih di angka 36,67 dengan jumlah pemesanan sebanyak 220 orang. Melihat kondisi ini tentunya hasil penjualan produksi KWT Ayu Tangkas perlu peningkatan yang lebih signifikan agar mampu memberikan pendapatan yang layak terhadap anggotaanggotanya. Berikut data hasil penjualan produksi kue KWT Ayu Tangkas yang diambil dalam enam bulan terakhir sebelum adanya promosi melalui sosial media instagram. 
Tabel 1. Banyaknya Pemesanan Kue Hasil Produksi KWT Ayu Tangkas di Desa Megati Januari-Juni 2018

\begin{tabular}{ccc}
\hline No. & Bulan & Pemesanan \\
\hline 1 & Januari & 25 \\
2 & Februari & 36 \\
3 & Maret & 20 \\
4 & April & 45 \\
5 & Mei & 50 \\
6 & Juni & 44 \\
Total & & 220 \\
\hline
\end{tabular}

Data banyaknya pemesanan kue hasil produksi KWT Ayu Tangkas di Desa Megati selama enam bulan yaitu bulan Januari sampai bulan Juni Tahun 2018 dapat digambarkan melalui diagram batang seperti pada gambar 1 sebagai berikut.

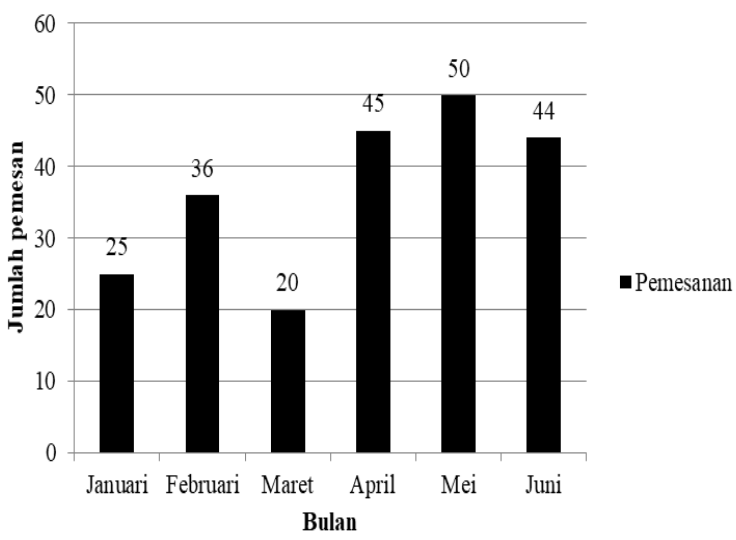

Gambar 1. Jumlah Pemesanan Hasil Produksi Tahun 2018

Pada gambar 1 di atas dapat dijelaskan bahwa penjualan tertinggi ada di bulan Mei yaitu sebanyak 50 pemesanan dan penjualan terendah ada di bulan Maret yaitu sebanyak 20 pemesanan. Jumlah total pemesanan selama enam bulan yaitu sebanyak 220 pemesan dengan rata-rata 36,67 . Secara hitung- hitungan statistik, angka ini masih jauh dari harapan penjualan produksi KWT Ayu Tangkas sebagai sumber pendapatan.

Mulai tahun 2019, KWT Ayu Tangkas mencoba untuk memanfaatkan sosial media berupa instagram untuk membantu memasarkan produknya dengan harapan dapat menjangkau konsumen yang lebih banyak dan daerah yang lebih luas. Promosi dengan media sosial media instagram cukup membantu dalam memperkenalkan produk KWT Ayu Tangkas melalui fitur instagram bussinees, dengan harapan dapat menghemat biaya, tenaga, dan waktu (Luthfi et al. 2017) menyatakan bahwa promosi melalui instagram dapat dengan mudah meningkatkan penjualan karena alat dan strategi berkomunikasi dengan konsumen juga lebih mudah.

Dengan nama akun "Sanganan Megati", promosi lewat akun instagram selama 6 bulan telah mampu menarik followers diatas 500 dan terus bertambah setiap harinya. Dari hasil promosi juga diperoleh peningkatan pemesanan kue dibandingkan sebelumnya yaitu tidak hanya ketika ada upacara agama saja, melainkan saat ada acara rapat di sekolah, pemesanan untuk reseller di warung, sampai pemesanan untuk konsumsi pribadi sehari-hari. Berikut banyaknya pemesanan hasil produksi KWT Ayu Tangkas dalam enam bulan terakhir.

Tabel 2. Banyaknya Pemesanan Kue Hasil Produksi KWT Ayu Tangkas di Desa Megati Januari-Juni 2019

\begin{tabular}{ccc}
\hline No. & Bulan & Pemesanan \\
\hline 1 & Januari & 128 \\
2 & Februari & 140 \\
3 & Maret & 152 \\
4 & April & 260 \\
5 & Mei & 388 \\
6 & Juni & 275 \\
Total & & 1.343 \\
\hline
\end{tabular}


Data banyaknya pemesanan kue hasil produksi KWT Ayu Tangkas di Desa Megati selama enam bulan yaitu bulan Januari sampai bulan Juni Tahun 2019 dapat digambarkan melalui diagram batang seperti pada gambar 2 sebagai berikut.

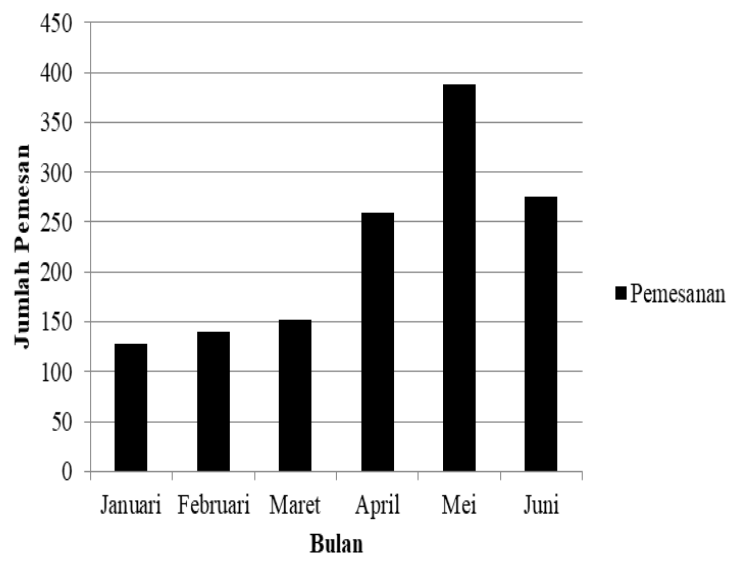

Gambar 2. Jumlah Pemesanan Hasil Produksi Tahun 2019

Berdasarkan Tabel di atas dapat dilihat bahwa terjadi peningkatan pemesanan kue produk KWT Ayu Tangkas selama enam bulan terakhir. Rata-rata hasil penjualan produksi kue selama enam bulan secara statistik sebesar 223,83 dengan total penjualan selama enam bulan sebanyak 1.343 orang. Hasil pemesanan paling banyak pada bulan Mei dengan jumlah pemesan sebanyak 388 orang. Pemesanan pada bulan ini lebih banyak oleh masyarakat khususnya yang beragama hindu untuk keperluan odalan (hari raya).

Dari hasil wawancara terhadap pemesan kue hasil produksi KWT Ayu Tangkas, rata-rata mereka mengetahui produk kue ini melalui instagram dan berasal dari luar desa, bahkan ada dari luar kecamatan. Pemesanan juga melayani Cash on Delivery (COD) sehingga konsumen merasa lebih mudah karena tidak harus datang ke tempat produksi kue.

Dibandingkan dengan data jumlah pemesanan hasil produksi tahun 2017-2018 yaitu sebelum adanya penggunaan media sosial instagram, memang ada perbedaan yang cukup signifikan. Dilihat dari jumlah pemesan sebanyak 220 orang selama enam bulan sebelum adanya promosi melalui media instagram, meningkat menjadi 1.343 orang setelah adanya promosi melalui instagram. Dengan kata lain terjadi peningkatan pemesan sebanyak 1.123 orang selama enam bulan.
Begitu juga dilihat dari rata-rata pemesan selama enam bulan terjadi peningkatan sebesar 187,16 dari tahun 2018 sampai tahun 2019 , yaitu sebelum promosi sebesar 36,67 perbulan menjadi 223,83 per bulan. Perbedaan ini terjadi tentunya karena jangkauan pemasaran produk KWT Ayu Tangkas menjadi lebih luas melalui media sosial instagram.

Berikut tabel perbandingan penjualan produksi kue KWT Ayu Tangkas sebelum dan sesudah dilakukan promosi melalui media sosial instagram.

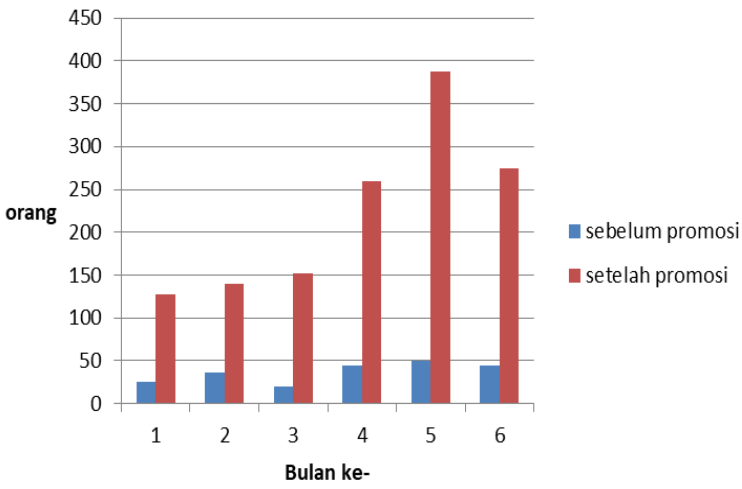

Gambar 3. Grafik penjualan sebelum dan setelah promosi

Berdasarkan gambar 3 yaitu sebelum dan sesudah adanya promosi lewat sosial media berupa instagram, memang ada perbedaan hasil penjualan yang cukup signifikan. Hampir di setiap bulan yang sama pada tahun yang berbeda terjadi peningkatan penjualan. Banyaknya pemesan tidak terlepas dari adanya promosi-promosi yang ditawarkan melalui instagram dengan cara unik dan menarik baik melalui foto maupun video. Ratarata pemesan juga berasal dari kalangan milenial, artinya orang-orang yang sudah melek teknologi, mengetahui trend yang sifatnya kekinian, serta gemar dalam mencoba hal-hal baru yang sifatnya konsumtif seperti makanan dan minuman.

Instagram memang menjadi media promosi yang cukup efektif untuk meningkatkan penjualan produksi, khususnya di era milenial seperti sekarang ini (Ayu et al. 2017). Ada beberapa fitur dalam instagram yang dimanfaatkan oleh KWT Ayu Tangkas dalam memasarkan produknya diantaranya posting foto, instagram story, followers, Geotagging, Hashtag, likes, komentar, serta quotes dalam setiap proses promosi yang dilakukan. Fitur-fitur tersebut berperan besar dalam setiap kegiatan yang mengandung 
unsur promosi produk KWT Ayu Tangkas di Desa Megati. Misalnya fitur posting foto yang bersifat tidak mengenal batasan jumlah postingan perhari, memberikan nilai lebih kepada pihak pengelola karena proses promosi yang dilakukan terus-menerus dan berulang-ulang akan lebih berpengaruh dalam menarik minat pelanggan dibandingkan promosi yang kurang berulang. Fitur posting foto juga mampu memberikan fungsi sebagai persuasi atau bersifat mempengaruhi daya tarik viewers atau konsumen.

Selain itu, fitur followers pada instagram memberikan dampak baik bagi promosi produk KWT Ayu Tangkas, dimana seorang followers akan menyampaikan informasi ke beberapa pihak dekatnya dan memberikan peluang besar untuk membujuk bahkan mengajak orang-orang di dekatnya agar mau menikmati produk yang diinformasikan. hal tersebut pun didukung dengan adanya fitur berupa hashtag yang akan menghubungkan pengguna satu dengan pengguna lainnya. Dengan adanya fitur seperti ini maka informasi akan lebih mudah diketahui masyarakat luas khususnya pengguna instagram, serta lebih mudah memilih produk yang diinginkan melalui tampilan gambar yang menarik. (Untari \& Fajariana 2018) menyatakan bahwa foto dan video pada instagram mampu memberi audiens informasi menarik dengan cara baru dan unik.

Melalui foto makanan yang menarik, akun Instagram Sanganan Megati berusaha untuk membuat followers tertarik, sehingga mereka mau membaca informasi lebih lanjut yang tertera pada caption. Penulisan caption dalam akun Instagram Sanganan Megati memiliki pola yang hampir sama, yaitu informatif dan ringkas. Mengingat akun instagram Sanganan Megati masih berumur beberapa bulan, sangat penting untuk menjaga konsistensi serta selalu melakukan inovasi yang sifatnya menarik dan kreatif. Informasi yang ditulis dalam caption umumnya adalah nama makanan, keunikan, label harga, dan kalimat yang memperjelas tulisan yang ada di gambar. Beberapa caption juga diberi emoticon yang disesuaikan dengan isi pesan, sehingga menampilkan kesan ramah dan menarik perhatian. Penulisan caption yang digabungkan dengan emoticon ini ditujukan untuk mengantisipasi anak-anak muda yang tidak suka membaca terlalu banyak tulisan (Reinhart et al. 2019).

Melihat peran sosial media instagram begitu efektif dalam membantu promosi produk KWT Ayu Tangkas di Desa Megati, maka para anggota selalu berupaya untuk menggunakan strategi promosi dan mengeksplorasi fitur-fitur yang ada pada instagram yang belum dimanfaatkan selama ini dengan optimal. Misalnya untuk menarik followers yang lebih banyak, bisa mencari seorang selebgram yang sudah memiliki followers yang cukup banyak untuk membantu mempromosikan produk KWT Ayu tangkas.

Pemanfaatan instastory juga perlu dibuat semenarik mungkin dan sesering mungkin ketika ada varian produk yang baru. Instastroy juga bisa dibuat mulai dari tahap pembuatan kue sampai kue itu siap untuk dijual. Hal ini juga sempat dilakukan KWT Ayu Tangkas bersama peneliti dengan mengundang atau mendatangkan pakar yang memang ahli di bidang pembuatan serta penyajian kue. Pakar ini memberikan pelatihan tentang cara pembuatan kue untuk dipasarkan dengan menitikberatkan pada kualitas berupa rasa, warna, tekstur, dan cara penyajian. Kue yang dihasilkan berupa kue sus, kue kering, kue getuk, dan lain sebagainya.

Langkah-langkah pembuatan kue mulai dari penyediaan bahan-bahan, tahap pembuatan, sampai tahap akhir yaitu penyajian kue yang dibuat semenarik mungkin dan divideokan melalui aplikasi instasory lewat instagram disamping juga foto dan video lainnya. dengan adanya instastory ini, mampu memberikan kesan yang lebih terbuka kepada konsumen tentang hasil produksi KWT Ayu Tangkas. Konsumen disamping melihat rasa dan harga, tentunya juga mempertimbangkan kualitas kue dari segi kebersihan melalui cara pembuatan yang bisa dilihat secara langsung, sehingga aspek "sukla" dalam hal ini bisa lebih ditonjolkan.

Terakhir adalah rata-rata konsumen lebih memilih untuk memesan jenis kue secara online, dan meminta penjual dalam hal ini KWT Ayu Tangkas untuk langsung membawakan pesanan itu ke rumah, kantor, atau tempat tertentu. Layanan yang disebut Cash on delivery ini juga mulai dirancang dan disempurnakan agar konsumen semakin mudah dan nyaman memesan kue hasil produksi KWT Ayu Tangkas di instagram, melalui fitur lainnya seperti aplikasi whatsapp, facebook, line, dan sebagainya yang bisa diakses dengan cepat dan mudah. Faktor efisiensi inilah yang menjadi focus pihak promosi agar penjualan hasil produksi bisa terus ditingkatkan kedepannya. 


\section{PENUTUP}

Berdasarkan hasil dan pembahasan dapat disimpulkan bahwa media sosial instagram sebagai media promosi mampu meningkatkan penjualan produksi KWT Ayu Tangkas di Desa Megati Kecamatan Selemadeg Timur Kabupaten Tabanan. Dilihat dari jumlah pemesan sebanyak 220 orang selama enam bulan sebelum adanya promosi melalui media instagram, meningkat menjadi 1.343 orang setelah adanya promosi melalui instagram. Dengan kata lain terjadi peningkatan pemesan sebanyak 1.123 orang selama enam bulan. Begitu juga dilihat dari rata-rata pemesan selama enam bulan terjadi peningkatan sebesar 187,16 dari tahun 2018 sampai tahun 2019, yaitu sebelum promosi sebesar 36,67 perbulan menjadi 223,83 per bulan. Peningkatan penjualan ini dapat dilihat dari meningkatnya jumlah pemesanan produk kue dari dalam dan luar desa setiap bulannya, sehingga berdampak pada peningkatan pendapatan KWT Ayu Tangkas di Desa Megati. Berdasarkan hasil ini berarti promosi berbasis sosial media instagram berpengaruh terhadap penjualan hasil produksi KWT Ayu Tangkas di Desa Megati Kabupaten Tabanan.

Ada beberapa saran yang dapat diberikan terkait penelitian ini diantaranya adalah 1) Menambah variasi produk kue yang dibuat agar pilihan konsumen tidak menjadi terbatas, 2) Lebih memaksimalkan lagi penggunaan fitur-fitur instagram, diantaranya fitur geotagging yang dapat memudahkan followers dalam mengakses informasi alamat dan live instagram (insta story) dapat menjadi media pemasaran langsung, 3) hendaknya pihak KWT Ayu Tangkas memiliki admin khusus yang bertugas untuk mengelola akun instagram "Sanganan Megati" sehingga penggunaannya akan lebih maksimal lagi.

\section{DAFTAR PUSTAKA}

Ayu, Komang, Pradnya Indrawati, I Nyoman Sudiarta, and I Wayan Suardana. 2017. "EFEKTIVITAS IKLAN MELALUI MEDIA SOSIAL FACEBOOK DAN INSTAGRAM SEBAGAI SALAH SATU STRATEGI PEMASARAN DI KRISNA OLEH-OLEH KHAS BALI" 17 (2): 78-83.

Indika, Deru R, and Cindy Jovita. 2017. "Media Sosial Instagram Sebagai Sarana Promosi Untuk Meningkatkan Minat Beli
Konsumen." Jurnal Bisnis Terapan 1 (01): 25. https://doi.org/10.24123/ibt.v1i01.296.

Industri, Pengelola, Kreatif Fashion, and D I Kota. 2015. “JIPSi” V (2).

Nuraini, Luthfi, Sandra Putri, and Isnurrini Hidayat Susilowati. 2017. "PELAKSANAAN PROMOSI MELALUI MEDIA SOSIAL INSTAGRAM" XVII (2): 226-36.

Priambada, Swasta. 2015. "MANFAAT PENGGUNAAN MEDIA SOSIAL PADA USAHA KECIL MENENGAH (UKM)." Seminar Nasional Sistem Informasi Indonesia.

Purwidiantoro, Moch Hari, Kristanto Dany Fajar S.W, and Widiyanto Hadi. 2016. "Pengaruh Penggunaan Media Sosial Terhadap Pengembangan Usaha Kecil Menengah (UKM)." Jurnal EKA CIDA 1 (1): 30-39.

Setiawati, Mila, Yulfita ' Aini, and Welven Aida. 2015. "PENGARUH MEDIA SOSIAL TERHADAP MINAT BELI KONSUMEN (Studi Kasus Mahasiswa Manajemen Universitas Pasir Pengaraian)."

Sondakh, Reinhart Abedneju, Endang Erawan, and Sarwo Edy Wibowo. 2019. "PEMANFAATAN MEDIA SOSIAL INSTAGRAM PADA AKUN @ GEPREKEXPRESS DALAM MEMPROMOSIKAN RESTORAN" 7 (1): 279-92.

Subang, Kabupaten, Jawa Barat, Echsan Rizki Isnanda, Agnes Susanto, Ahmad Farhan Mubarok, Ananda Putri Upi M, Elisabeth Stephanie, Deriza Aditya Putra, Ira Irawati, and Enjat Munajat. 2013. "Penggunaan Media Tersebut Sebagai Alat Jaringan Sosial Tidak Hanya Dalam Membagikan Kegiatan Si Pengguna Namun Dapat Meningkatkan Penggunaan Bisnis Secara."

Untari, Dewi, and Dewi Endah Fajariana. 2018. "Strategi Pemasaran Melalui Media Sosial Instagram ( Studi Deskriptif Pada Akun @ Subur_Batik )" 2 (2): 271-78. 